\title{
Differential protein analysis of chicken skin infected with Marek's disease virus
}

\author{
X. CHEN ${ }^{1}, \mathrm{X} . \mathrm{HU}^{2}, \mathrm{CH} . \mathrm{YU}^{2}, \mathrm{~K} . \mathrm{QIAN} N^{1,2,3}, J . \mathrm{YE}^{1,2,3}, \mathrm{~A} . \mathrm{QIN}^{1,2,3^{*}}$
}

\begin{abstract}
${ }^{1}$ Ministry of Education Key Lab for Avian Preventive Medicine, Yangzhou University, No. 12 East Wenhui Road, Yangzhou, Jiangsu, 225009, P. R. China; ${ }^{2}$ Key Laboratory of Jiangsu Preventive Veterinary Medicine, Yangzhou University, No.12 East Wenhui Road, Yangzhou, Jiangsu,225009, P. R. China; ${ }^{3}$ Jiangsu Co-innovation Center for Prevention and Control of Important Animal Infectious Diseases and Zoonoses, Yangzhou, 225009, P. R. China
\end{abstract}

Received March 15, 2013; accepted February 24, 2014

\begin{abstract}
Summary. - The skin and feather follicle epithelia of birds infected with Marek's disease virus (MDV) are the sites of infectious virus particle formation and shedding. However, the host responses and protein networks involved in the production of virus particles in the skin of MDV-infected chickens are poorly understood. This current study aimed to analyze the differential protein expression patterns in skin between MDV-infected and uninfected specific pathogen-free (SPF) chickens 28 days post infection (dpi) by combining two-dimensional electrophoresis (2-DE) and mass spectrometry (MS) analyses. Through 2-DE analysis, our results revealed 23 proteins whose expression changed significantly following infection, of which 16 proteins were confirmed by MS. The identified proteins were functionally classified into 5 groups: immune-related, cell regulatory, cytoskeletal, metabolism-related and transport proteins. A single protein, beta 2-microglobulin, was further confirmed by real-time quantitative PCR. Beta 2-microglobulin expression was significantly increased in the infected group $28 \mathrm{dpi}$. This indicates that beta 2 -microglobulin might play very important roles in the viral evasion from host immune response.
\end{abstract}

Keywords: Marek's disease virus; skin; two-dimensional electrophoresis; beta 2-microglobulin; real time quantitative PCR

\section{Introduction}

Marek's disease virus (MDV) is a highly cell-associated alpha herpesvirus that replicates in genetically resistant and susceptible chickens. Symptoms of the classical form of Marek's disease (MD), such as tumors or lymphocyte infiltrations, develop as early as 3-4 weeks post infection and are found in the neural and visceral tissues (Calnek, 2001). In MDV infection, the feather follicle epithelium (FFE) plays an important role in the transmission of MDV, as it constitutes the site of infectious virus particle formation and virus shed-

*Corresponding author. E-mail: aijian@yzu.edu.cn; phone: +86514-87979217.

Abbreviations: $\mathrm{MD}=$ Marek's disease; $\mathrm{MDV}=\mathrm{MD}$ virus; $\mathrm{FFE}=$ feather follicle epithelium; MHC I = major histocompatibility complex class I; SPF = specific pathogen-free; $\mathrm{dpi}=$ days post infection; $2-\mathrm{DE}=$ two-dimensional electrophoresis; $\mathrm{CEFs}=$ chicken embryo fibroblasts; $\beta 2 \mathrm{M}=$ beta 2 -microglobulin ding (Calnek et al., 1970). The MDV genome can be detected in the feather tips of infected birds as early as 7 days post infection (dpi) by real-time PCR with SYBR green staining. MDV expression culminates 14-28 dpi and then gradually decreases. The virus genome load was greater in feathers than in other tissues, such as the spleen and lymphoid tissues (Abdul-Careem et al., 2006; Baigent et al., 2005). Due to their important roles in the release and transmission of viruses, host responses induced in the feather follicle epithelium and the skin have recently attracted significant attention. The infiltration of CD4+ and CD8+ T cells and the enhanced expression of cytokines, such as IL-18, IL-6, IFN- $\gamma$, and the major histocompatibility complex class I (MHC I) genes, were found in the feather pulp of MDV-infected chickens (Abdul-Careem et al., 2008, 2009). However, previous studies on feathers and skin have been limited to examining the level of transcription of individual genes. It has become obvious that transcriptional profiles are not always directly correlated with actual protein levels or protein functions. 
At the present time, the protein networks involved in the production of virus particles in the skin of MDV-infected chickens are poorly understood.

Protein expression can be studied by proteomic assays using two-dimensional gel electrophoresis (2-DE) as a central tool for protein separation. Proteomic analyses have been used extensively for the investigation of virulence factors, host responses to pathogens and viral pathogenesis. Host responses induced by MDV infection have been observed in the thymus, spleen and bursa of Fabricius (Hu et al., 2012; Lu et al., 2010; Thanthrige-Don et al., 2009, 2010). In this paper, we used the skins of MDV-infected chickens 28 dpi to obtain 2-DE profiles of total soluble proteins in order to analyze the differential protein expression between MDV-infected and uninfected specific pathogen-free (SPF) chickens.

\section{Materials and Methods}

Infectious virus. MDV serotype 1 strain RB1B stock was maintained in our laboratory and grown in secondary chicken embryo fibroblasts (CEFs) at $37^{\circ} \mathrm{C}$ in a $5 \% \mathrm{CO}_{2}$ atmosphere. The cells were harvested for the measurement of viral titers when the cytopathic effect became clearly visible in approximately $80 \%$ of the cells.

Experimental animals. All chickens used in this study were 1-day-old SPF white Leghorn chickens obtained from Merial Vital (Laboratory Animal Technology Co. Ltd., China). The animals were divided randomly into two groups and were housed in an isolation facility. One group $(\mathrm{n}=24)$ was inoculated intraperitoneally with 800 PFU of the MDV RB1B strain. A second group ( $n=24)$ was used as uninfected controls. Infected and uninfected birds were kept in separate units with similar environmental conditions. All animal experiments were conducted in accordance with the guidelines provided by the Chinese Council on Animal Care. All experiments complied with institutional animal care guidelines and were approved by the University of Yangzhou Animal Care Committee (protocol number 06R015).

Skin sample preparation. Three chickens from each group were euthanized using $\mathrm{CO}_{2}$ inhalation $28 \mathrm{dpi}$. Skin samples from the abdomen and neck with downy feathers were collected. Adipose and muscle tissues adhered to the skin were removed as much as possible. After taking each sample $(0.5 \mathrm{~cm} \times 0.5 \mathrm{~cm})$ for formalin fixation, the remaining samples were frozen at $-70^{\circ} \mathrm{C}$.

Microscopy observation. Formalin-fixed paraffin-embedded tissues from each group were sectioned $(5 \mu \mathrm{m})$, stained with hematoxylin and eosin, and examined under a light microscope (Leica DM750).

Protein extraction. Frozen skin samples were ground in liquid nitrogen with a pre-chilled mortar and pestle, and $50 \mathrm{mg}$ of tissue powder was dissolved in lysis buffer containing $8 \mathrm{~mol} / \mathrm{l}$ urea, 2\% CHAPS, 50 mmol/l DTT, 0.2\% Bio-Lyte 3/10 ampholyte and a cocktail of protease inhibitors. The samples were incubated at room temperature for approximately $2 \mathrm{hr}$ with occasional shak- ing, and then sonicated on ice in 3-4 cycles with 30 second bursts. After centrifugation at $12,000 \mathrm{rpm}$ for $1 \mathrm{hr}$, the supernatants were transferred to clean $1.5 \mathrm{ml}$ tubes. The total protein concentrations of the tissue lysates were determined using a Protein Assay kit (BioRad Laboratories), and the samples were stored at $-70^{\circ} \mathrm{C}$ prior to two-dimensional electrophoresis (2-DE).

Two-dimensional electrophoresis (2-DE). For each sample, approximately $400 \mu \mathrm{g}$ of proteins were diluted in rehydration buffer (with the same composition as the lysis buffer) to a total volume of $300 \mu \mathrm{l}$ and were loaded into a $17 \mathrm{~cm}$ IPG strip (pH 5-8). 2-DE was performed as previously described (Chen et al., 2011). Briefly, isoelectric focusing was carried out according to the recommended parameters $(250 \mathrm{~V}$ for $1 \mathrm{hr}, 1,000 \mathrm{~V}$ for $2 \mathrm{hr}, 8,000 \mathrm{~V}$ for $5 \mathrm{hr}$, and $8,000 \mathrm{~V}$ for $60,000 \mathrm{Vhs})$. After equilibration, each IPG strip was placed on a $12 \%$ SDS-polyacrylamide gel for separation in the second dimension. Each sample was analysed in triplicate, using three biological replicates from each group to account for variability among animals. The control and infected 2-DE gel images were scanned with UMAX PowerLook 2100xl (UMAX, China), and the images were exported in TIFF format. Six images $(3 \times 2$ groups) with higher resolution were analyzed using PDQuest 8.0.1 software (Bio-Rad Laboratories). The gel spots for which intensity abundances were observed to change approximately two-fold or greater, as detected by the software, were further analyzed with Student's $t$-test.

Mass spectrometry and database searches. After analysis with PDQuest 8.0.1 and Student's $t$-test, 20 altered spots ( $\geq 2.0$-fold change and $\mathrm{P} \leq 0.05$ ) were cut from the gels and submitted to Southern Medical University (Guangzhou, China) for analysis using matrix-assisted laser desorption ionisation time-of-flight mass spectrometry (MALDI-TOF MS). The protein samples were digested into peptides with trypsin at $37^{\circ} \mathrm{C}$. The peptides were then ionized and mass spectra were obtained following ion detection in the MALDI trap together with an Applied Biosystems 4700 Proteomics Analyzer (Applied Biosystems). The UV laser was operated at $200 \mathrm{~Hz}$ with a wavelength of $355 \mathrm{~nm}$. The accelerated voltage was $20 \mathrm{kV}$. A trypsin fragment peak served as an internal standard for mass calibration, and the mass spectra for all samples were obtained using the default acquisition mode. The raw MS data output files were searched by GPS Explorer using MASCOT (Matrix Science, UK). The following search parameters were applied: the peptide molecular mass ranged from 800 to $4,000 \mathrm{Da}$, the alkylation of cysteine by carbamidomethylation and oxidation of methionine were considered as possible modifications, the peptide masses were monoisotopic, a mass tolerance of $50 \mathrm{ppm}$ was used and 1-2 missed cleavages were allowed per peptide. Molecular functions and biological processes for identified proteins were assigned according to the Gene Ontology database and prior literature annotation.

Identification of B2M $m R N A$ by real-time quantitative PCR. From each sample, $50 \mathrm{mg}$ of tissue powder ground in liquid nitrogen were used for total RNA extraction using the Total RNA Miniprep Kit (Axygen, USA), followed by DNase I (Fermentas, Canada) treatment for $30 \mathrm{~min}$ to remove genomic DNA. Reverse transcription of total RNA $(1 \mu \mathrm{g})$ was carried out using a reverse 


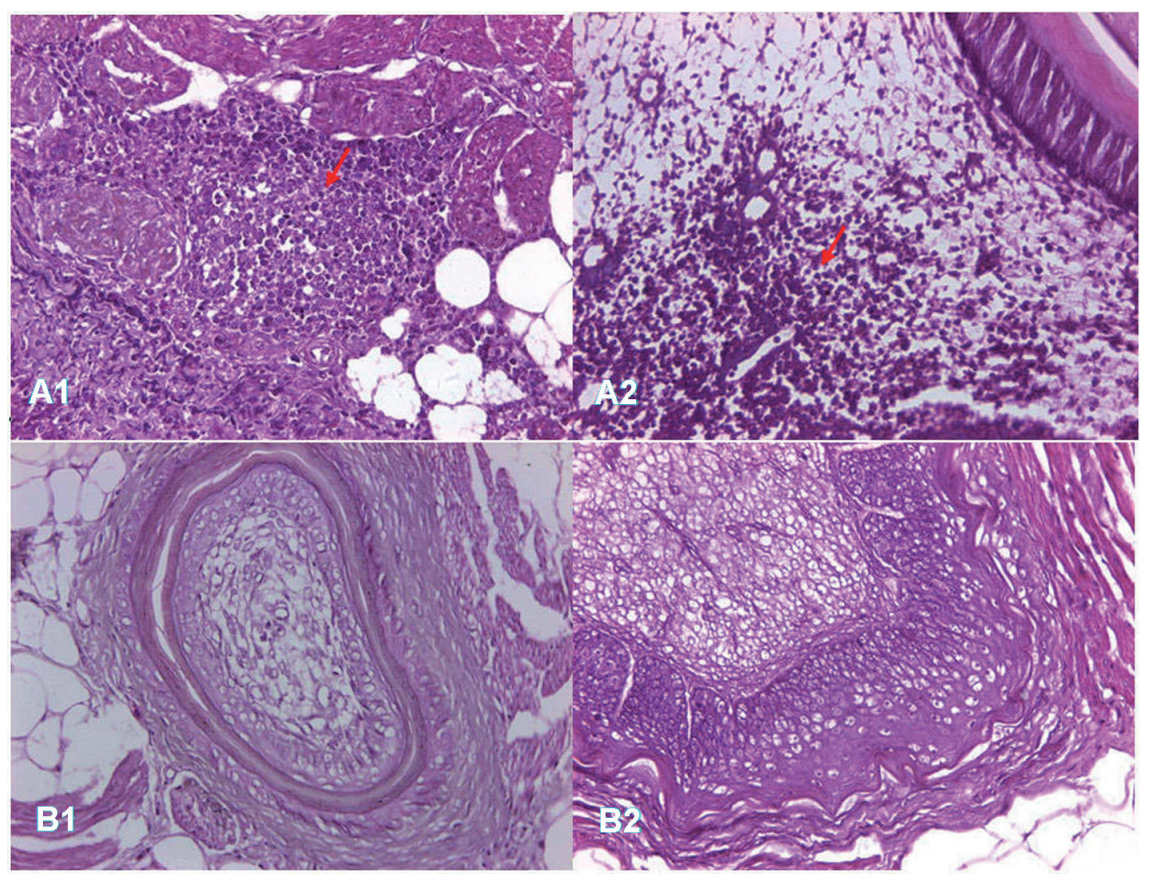

Fig. 1

Lesions of MDV-infected chicken skin stained with hematoxylin $(10 \times 40)$

Lymphocytes of multiple sizes and morphologies (indicated by arrows) could be observed infiltrating the subcutaneous tissue and feather pulp isolated from the infected group. A1: Subcutaneous tissue of infected group, A2: feather pulp of infected group; B1: subcutaneous tissue of control group, B2: feather pulp of control group.

transcription kit (Takara, Japan) according to the manufacturer's instructions.

The sequences of primers were obtained from Li et al. (2005). For the beta 2-microglobulin gene, the primers were 5 '-AAG GAG CCG CAG GTC TAC-3' and 5'-CTT GCT CTT TGC CGT CAT AC-3'. For the beta-actin gene (internal control), the primers were $5^{\prime}$-GAG AAA TTG TGC GTG ACA TCA- 3 ' and 5 '-CCT GAA CCT CTC ATT GCC A-3'. The primers were synthesized by Shenergy Biocolor Bioscience \& Technology Company (China). Real-time quantitative PCR experiments were conducted using the ABI 7500 system (Applied Biosystems, USA) in a final reaction volume of $20 \mu$, including $10 \mu$ of SYBR Green I (ABI, $2 \times), 2 \mu$ of cDNA (reverse transcribed from 50 ng total RNA) and $0.4 \mu \mathrm{mol} / \mathrm{l}$ of both the forward and reverse primers. Three replicates of each sample and a negative control (without template) for each gene were set to amplify simultaneously. The optimal thermal cycling was carried out using the following procedure: $95^{\circ} \mathrm{C} / 10 \mathrm{~min}$, followed by 40 cycles of $95^{\circ} \mathrm{C} / 15 \mathrm{sec}$ and $64^{\circ} \mathrm{C} / 1 \mathrm{~min}$, melting curve analysis at $95^{\circ} \mathrm{C} / 15 \mathrm{sec}, 64^{\circ} \mathrm{C} / 1 \mathrm{~min}$ and $95^{\circ} \mathrm{C} / 30 \mathrm{sec}, 64^{\circ} \mathrm{C} / 15 \mathrm{sec}$. Fluorescent acquisition was performed at $64^{\circ} \mathrm{C} / 1 \mathrm{~min}$. After amplification, the data were analyzed using the $2^{-\triangle \Delta C T}$ method (Livak and Schmittgen, 2001). Specifically, [(CT beta 2-microglobulin - CT beta-actin) infected group - (CT beta 2-microglobulin - CT beta-actin) control group] was used for the calculation.

\section{Results}

Skin lesions of chickens infected with the MDV RB1B strain

Visible skin lesions in the infected group did not develop until 28 dpi. Small hemorrhagic skin spots were observed on some MDV-infected chickens. Microscopic analysis showed that a large number of lymphocytes had infiltrated the feather pulp, subcutaneous tissue and small subcutaneous vessels of three chickens from the infected group (Fig. 1).

Proteomic analysis of skin tissues from infected and control chickens

The 2-DE gels allowed the separation of total proteins isolated from chicken skin. Analysis using PDQuest 8.0.1 revealed that approximately 500-600 polypeptide spots could be detected on each 2-DE gel. The match rate between the infected and control group was approximately $86 \%$. A total of 23 differentially expressed protein spots were detected in chickens from the infected group relative to the control group, including 7 newly induced (marked "New" on 2-DE gels) proteins, 13 up-regulated 

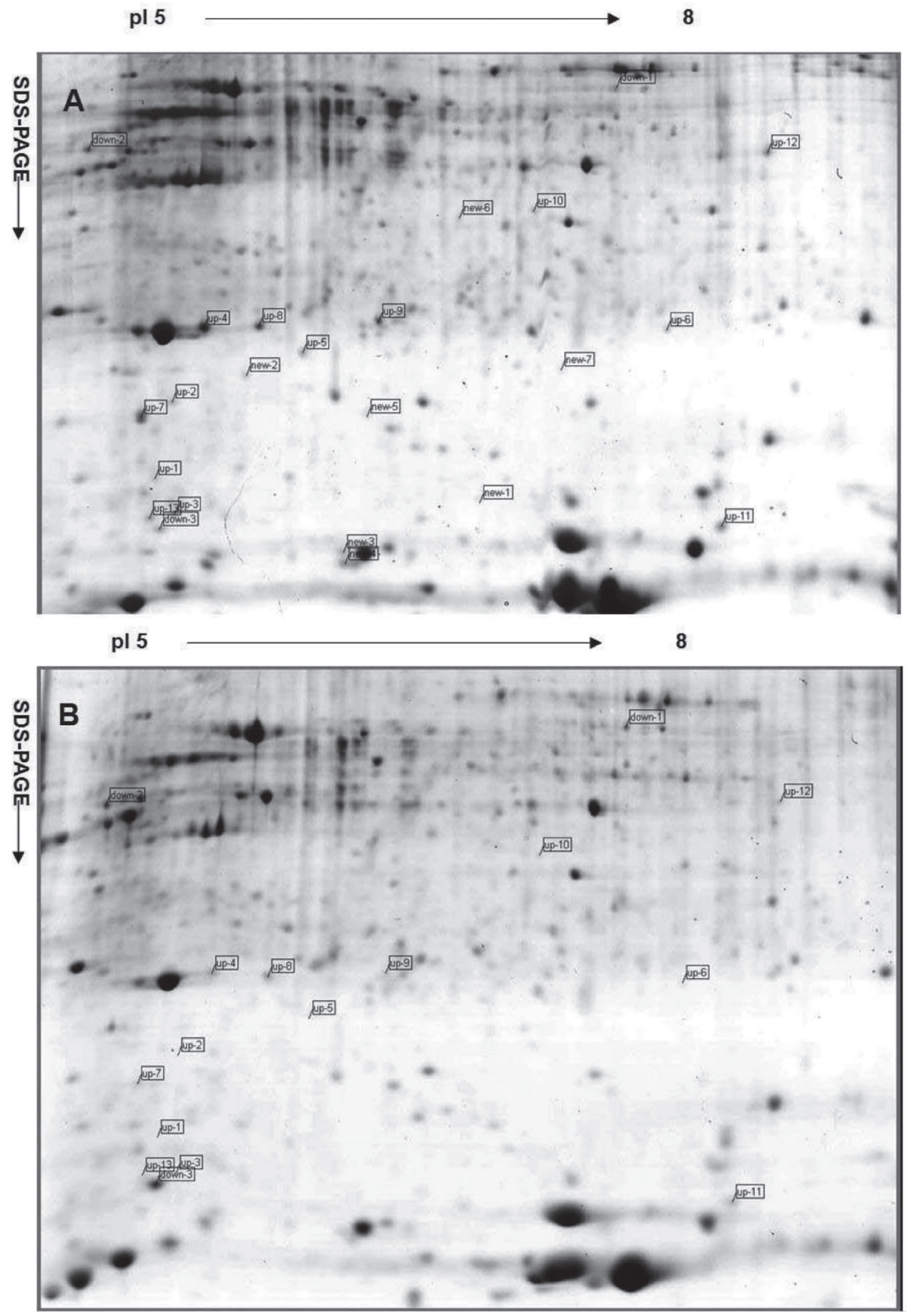

Fig. 2

Two-dimensional gel electrophoresis analysis of chicken skin

Proteins were separated in the first dimension based on their isoelectric points within $\mathrm{pH} 5.0-8.0$ and in the second dimension by molecular mass using SDS-PAGE (12\% acrylamide). The gels were stained using blue silver staining. Differentially expressed protein spots were annotated (New: newly induced; Up: up-regulated; Down: down-regulated). A: MDV-infected group; B: uninfected control group. 
Table 1. Differentially expressed proteins identified by MALDI-TOF/TOF in the skin of chickens infected with MDV

\begin{tabular}{|c|c|c|c|c|c|c|c|}
\hline No. & $\begin{array}{l}\text { Spot on } \\
\text { gels }\end{array}$ & $\begin{array}{l}\text { Accession } \\
\text { No. }\end{array}$ & Protein name & $\begin{array}{l}\text { Protein } \\
\text { score }\end{array}$ & $\begin{array}{l}\text { Protein } \\
\text { score } \\
\text { C.I. } \%\end{array}$ & $\begin{array}{l}\text { Peptides } \\
\text { matched }\end{array}$ & Peptide information \\
\hline 1 & Up-1 & IPI00570959 & $\begin{array}{l}\text { Putative uncharac- } \\
\text { terized protein }\end{array}$ & 80 & 99.977 & 6 & $\begin{array}{l}\text { YQHEDGR FIVYSYK LVQTAELTK NTEDLTEEWLR } \\
\text { QLVVLDEEHEGISPDELKDELPER } \\
\text { VSYPLCFIFSSPVGCKPEQQMMYAGSK }\end{array}$ \\
\hline 2 & Up-2 & IPI00590587 & $\begin{array}{l}\text { Myosin light chain } \\
\text { 1, cardiac muscle }\end{array}$ & 128 & 100 & 14 & $\begin{array}{l}\text { EAFSLFDR EVEFNPASIK KEVEFNPASIK ALGQNPTQAEVMK } \\
\text { VEFTPDQIEEFK DTGTYEDFVEGLR VLGRPKQEEMNSK } \\
\text { VFDKEGNGTVMGAELR TKDTGTYEDFVEGLR EGNGTVM- } \\
\text { GAELRHVLR EEPKPAPKPAEPEPKK MIDFETFLPMLQHISK } \\
\text { MIDFETFLPMLQHISKTK VEFTPDQIEEFKEAFSLFDR }\end{array}$ \\
\hline 3 & Up-3 & IPI00574195 & Albumin serum & 66 & 99.425 & 15 & $\begin{array}{l}\text { EKAKGVSVK NECFLSFK YNDLKEETFK DSYGAMADCCSK } \\
\text { VSFLGHFIYSVAR AVAMITFAQYLQR ADPERNECFLSFK AD- } \\
\text { PERNECFLSFK IAKGYESLLEKCCK MMSNLCSQQDVFSGK } \\
\text { GVSVKQQYFCGILKQFGDR HPFLYAPAILSFAVDFEHALQSC- } \\
\text { CK CCKQSDINTCFGEEGANLIVQSRATLGIGA } \\
\text { CVANEDAPECSKPLPSIILDEICQVEK VSQPDFVQPYQRPASD- } \\
\text { VICQEYQDNR }\end{array}$ \\
\hline 4 & $\mathrm{Up}-4$ & IPI00580765 & Apolipoprotein A-I & 296 & 100 & 22 & $\begin{array}{l}\text { LEEIREK GHVEELRK LTPVAEEAR DLEEVKEK LTPVAQELK } \\
\text { LTPYAENLK VMEQLSNLR MTPLVQEFR NLAPYSDELR } \\
\text { GIPQASEYQAK LISFLDELQK WTEELEQYR LREDMAPYYK } \\
\text { KNLAPYSDELR IRPFLDQFSAK ERLTPYAENLK EKMT- } \\
\text { PLVQEFR EMWLKDTEALR MTPLVQEFRER EKIRPFLDQF- } \\
\text { SAK IRDMVDVYLETVK ASGKDAIAQFESSAVGK SFWQH- } \\
\text { DEPQTPLDR L }\end{array}$ \\
\hline 5 & Up-5 & IPI00580765 & Apolipoprotein A-I & 115 & 100 & 16 & $\begin{array}{l}\text { GHVEELRK LTPVAEEAR LTPVAQELK LTPYAENLK } \\
\text { VMEQLSNLR MTPLVQEFR NLAPYSDELR GIPQASEYQAK } \\
\text { LISFLDELQK WTEELEQYR LREDMAPYYK KNLAPYS- } \\
\text { DELR IRPFLDQFSAK EKMTPLVQEFR EMWLKDTEALR } \\
\text { DLEEVKEKIRPFLDQFSAK }\end{array}$ \\
\hline 6 & Up-6 & IPI00582452 & $\begin{array}{l}\text { TPI1 Triosephos- } \\
\text { phate Isomerase }\end{array}$ & 365 & 100 & 15 & $\begin{array}{l}\text { IGVAAQNCYK SHVSDAVAQSTR LDEREAGITEK IIYGGSVT- } \\
\text { GGNCK GAFTGEISPAMIK SLGELIHTLNGAK IGVAAQN- } \\
\text { CYKVPK HVFGESDELIGQK TATPQQAQEVHEK MAPRK- } \\
\text { FFVGGNWK VVLAYEPVWAIGTGK RHVFGESDELIGQK } \\
\text { TATPQQAQEVHEKLR VAHALAEGLGVIACIGEK LSADTEV- } \\
\text { VCGAPSIYLDFAR }\end{array}$ \\
\hline 7 & Up-7 & IPI00578052 & $\begin{array}{l}\text { Myosin light chain } \\
1 \text {, skeletal muscle } \\
\text { isoform }\end{array}$ & 299 & 100 & 13 & $\begin{array}{l}\text { EQQDDFK SIKIEFSK HVLATLGEK EAFLLFDR ITLSQVG- } \\
\text { DIVR EGNGTVMGAELR ALGQNPTNAEINK ILGNPS- } \\
\text { KEEMNAK DQGTFEDFVEGLR VFDKEGNGTVMGAELR } \\
\text { GQEDSNGCINYEAFVK EQQDDFKEAFLLFDR ITFEEFLPM- } \\
\text { LQAAANNK } \\
\text { MTEEEVEELMKGQEDSNGCINYEAFVK }\end{array}$ \\
\hline 8 & Up-8 & IPI00580765 & Apolipoprotein A-I & 294 & 100 & 27 & $\begin{array}{l}\text { LEEIREK GHVEELRK LTPVAEEAR DLEEVKEK LTPVAQELK } \\
\text { LTPYAENLK VMEQLSNLR QKVELMQAK VMEQLSNLR } \\
\text { LSQKLEEIR MTPLVQEFR NLAPYSDELR GIPQASEYQAK } \\
\text { LISFLDELQK WTEELEQYR LREDMAPYYK KNLAPYSDELR } \\
\text { IRPFLDQFSAK ERLTPYAENLK LADNLDTLSAAAAK EKMT- } \\
\text { PLVQEFR EMWLKDTEALR AELTKDLEEVKEK WTEELEQYR } \\
\text { IRDMVDVYLETVK ASGKDAIAQFESSAVGK SFWQHDEPQT- } \\
\text { PLDR }\end{array}$ \\
\hline 9 & Up-9 & IPI00586893 & $\begin{array}{l}\text { Adipocyte fatty acid } \\
\text { binding protein }\end{array}$ & 88 & 99.994 & 10 & $\begin{array}{l}\text { ELGVGFATR MCDQFVGTWK LLSSENFEDYMK LGEEFDET- } \\
\text { TADDR LGEEFDETTADDRK VVDGNLLVECTMNNVTSK } \\
\text { KVVDGNLLVECTMNNVTSK MAGVAKPNLTISINGDVITIR } \\
\text { LLSSENFEDYMKELGVGFATR CDQFVGTWKLLSSENFED- } \\
\text { YMK }\end{array}$ \\
\hline
\end{tabular}




\begin{tabular}{|c|c|c|c|c|c|c|c|}
\hline No. & $\begin{array}{l}\text { Spot on } \\
\text { gels }\end{array}$ & $\begin{array}{l}\text { Accession } \\
\text { No. }\end{array}$ & Protein name & $\begin{array}{l}\text { Protein } \\
\text { score }\end{array}$ & $\begin{array}{l}\text { Protein } \\
\text { score } \\
\text { C.I. } \%\end{array}$ & $\begin{array}{l}\text { Peptides } \\
\text { matched }\end{array}$ & Peptide information \\
\hline 10 & Up-10 & IPI00574153 & $\begin{array}{l}\text { PGK1 Phos- } \\
\text { phoglycerate } \\
\text { kinase }\end{array}$ & 257 & 100 & 16 & $\begin{array}{l}\text { IVKDLMAK FHVEEEGK KELDYFAK FHVEEEGKGK AHSSM- } \\
\text { VGVHLPQK } \\
\text { LGDVYVNDAFGTAHR VQDKIQLISNMLDK FHVEEEG- } \\
\text { KGKDASGNK EVSFLKDCVGPEVEK VSHVSTGGGASLEL- } \\
\text { LEGK GCITIIGGGDTATCCAK ALESPERPFLAILG- } \\
\text { GAK ACANPANGSVILLENLR VVMRVDFNVPMKDHK } \\
\text { VLNNMQIGNSLFDEEGSK WNTEDKVSHVSTGGGASLEL- } \\
\text { LEGK }\end{array}$ \\
\hline 11 & Up-11 & IPI00597641 & $\begin{array}{l}\text { RBP7 } \\
\text { Similar to retinoid } \\
\text { binding protein } 7\end{array}$ & 254 & 100 & 11 & $\begin{array}{l}\text { DYMLQFK QDGDSFSIHTTSTF IGEEFEEDNKGLDNR IGEE- } \\
\text { FEEDNKGLDNRK } \\
\text { GWTHWLEGDDLHLELR VIKQDGDSFSIHTTSTFR SLVT- } \\
\text { WDNDKLICIQAGEK SLVTWDNDKLICIQAGEKK NRG- } \\
\text { WTHWLEGDDLHLELR QDGDSFSIHTTSTFRDYMLQFK } \\
\text { VIKQDGDSFSIHTTSTFR DYMLQFK } \\
\end{array}$ \\
\hline 12 & Up-12 & IPI00586105 & $\beta$-enolase & 118 & 100 & 17 & $\begin{array}{l}\text { ISVVEQEK TIGPALIEK KISVVEQEK VGAEVYHSLK } \\
\text { AAIAQAGYTDK DGRYHLDFK FGANAILGVSLAVCK VVIG- } \\
\text { MDVAASEFCR LAQSHGWGVMVSHR VNQIGSVTESIQACK } \\
\text { IAHGAEQHACNCLLLK SKFGANAILGVSLAVCKAGAAEK } \\
\text { LAMQEFMVLPVGAASFHDAMR } \\
\text { SGETEDTFIADLVVGLCTGQIK DYPVVSIEDPFDQD- } \\
\text { DWEAWKR } \\
\text { AAIAQAGYTDKVVIGMDVAASEFCR HIADLAGNTE- } \\
\text { LILPVPAFNVINGGSHAGNK }\end{array}$ \\
\hline 13 & New-2 & IPI00581424 & $\begin{array}{l}\text { Heat shock protein } \\
25\end{array}$ & 109 & 100 & 9 & $\begin{array}{l}\text { ETQNTDEK NFAPEQLSVK GSFSYKYEVLK GSFSYKYEVLKR } \\
\text { MHLAPFASSSLATR ETQNTDEKGSFSYK MHLAPFASSS- } \\
\text { LATRLGTVR ETQNTDEKGSFSYKYEVLK TLWPHAETIF- } \\
\text { SELQQEMEK }\end{array}$ \\
\hline 14 & New-3 & IPI00583199 & $\beta 2$-microglobulin & 89 & 99.997 & 4 & $\begin{array}{l}\text { NVLNCFAAGFHPPK VEHETLKEPQVYK LVHADFTPSSGSTY- } \\
\text { ACK } \\
\text { DGVPMEGAQYSDMSFNDDWTFQR }\end{array}$ \\
\hline 15 & New-7 & IPI00592568 & $\begin{array}{l}\text { Creatine kinase } \mathrm{M}- \\
\text { type }\end{array}$ & 63 & 98.798 & 4 & $\begin{array}{l}\text { GYSLPPHCSR DLFDPVIQDR FSAEEEFPDLSK } \\
\text { LSVEALNSLEGEFK }\end{array}$ \\
\hline 16 & Down-3 & IPI00820372 & TTR $15 \mathrm{kD}$ protein & 201 & 100 & 7 & $\begin{array}{l}\text { GSPAANVAVK VEFDTSSYWK AADGTWQDFATGK } \\
\text { KAADGTWQDFATGK } \\
\text { GLGLSPFHEYADVVFTANDSGHRH YTIAALLSPFSYSTTAV- } \\
\text { VSDPQE TTEFGEIHELTTEEQFVEGVYR }\end{array}$ \\
\hline
\end{tabular}

( $\geq 2.0$-fold change, marked "Up") proteins and 3 down-regulated ( $\geq 2.0$-fold change, marked "Down") (Fig. 2) proteins.

MS analysis and identification of differentially expressed proteins

The 20 spots with significantly altered expression patterns following infection were subjected to MALDI-TOF MS analysis, and 16 of the initial 20 were identified successfully. Among the identified proteins, three up-regulated protein spots that were similar in molecular weight but slightly different in isoelectric point were all shown to be apolipoprotein AI (apo AI). Other identified proteins included beta 2-microglobulin, heat shock protein 25, creatine kinase M-type, phosphoglycerate kinase, and so on (Table 1). According to gene ontology databases and literature review, the identified proteins were classified into the following 5 functional groups: immune-related, cell regulatory, cytoskeletal, metabolism-related and transport proteins (Table 2).

Real-time quantitative PCR analysis of beta 2-microglobulin

Beta 2-microglobulin and beta actin were amplified from all samples, whereas the negative control reactions yielded no products. The melting curves showed that PCR each product had a single peak. The CT (cross threshold) values of all the samples are listed in Table 3. The $2^{-\Delta \Delta C T}$ value was calculated using the $2^{-\triangle \Delta C T}$ method and determined to be 3.86. These results suggested that the mRNA levels of beta 2 -microglobulin are 3.86-fold greater in the infected group than in the uninfected-control group. 
Table 2. Functional classification of differentially expressed proteins

\begin{tabular}{|c|c|c|c|c|}
\hline Classification & Protein name & $\begin{array}{l}\text { Molecular } \\
\text { mass }(\mathrm{kD}) / \\
\text { pI }\end{array}$ & Major function & $\begin{array}{l}\text { Fold change in ex- } \\
\text { pression ( } t \text {-value })\end{array}$ \\
\hline \multirow[t]{2}{*}{ Immune-related proteins } & beta-2-microglobulin & $11.04 / 5.46$ & $\begin{array}{l}\text { Component of the class I major histocom- } \\
\text { patibility complex (MHC). Involved in the } \\
\text { presentation of peptide antigens to the } \\
\text { immune system }\end{array}$ & $3.7^{*}$ \\
\hline & Heat shock protein 25 & $18.14 / 6.31$ & Protein binding & $2.8^{*}$ \\
\hline Regulatory proteins & Putative uncharacterized protein & $16.7 / 5.19$ & $\begin{array}{l}\text { Calcium ion binding, growth factor ac- } \\
\text { tivity }\end{array}$ & $3.9^{*}$ \\
\hline \multirow{2}{*}{ Cytoskeletal proteins } & $\begin{array}{l}\text { Myosin light chain } 1 \text {, } \\
\text { cardiac muscle isoform }\end{array}$ & $21.98 / 5.22$ & Calcium ion binding & $3.0^{*}$ \\
\hline & $\begin{array}{l}\text { Myosin light chain 1, skeletal muscle } \\
\text { isoform }\end{array}$ & $20.88 / 4.96$ & $\begin{array}{l}\text { Calcium ion binding, } \\
\text { motor activity }\end{array}$ & $4.1^{*}$ \\
\hline \multirow{5}{*}{ Metabolism-related proteins } & Creatine kinase M-type & $4.3 / 6.5$ & ATP binding, creatine kinase activity & $2.5^{*}$ \\
\hline & beta-enolase & $47.16 / 7.28$ & $\begin{array}{l}\text { Magnesium ion binding, phosphopyruvate } \\
\text { hydratase activity }\end{array}$ & $5.1^{\star *}$ \\
\hline & Apolipoprotein A- $\mathrm{I}^{1}$ & $30.66 / 5.58$ & Lipid metabolism & $8.9^{* *} / 3.5^{*} / 5.2^{* *}$ \\
\hline & TPI1 Triosephosphate isomerase & $26.60 / 6.71$ & Triose-phosphate isomerase activity & $2.8^{*}$ \\
\hline & PGK1 Phosphoglycerate kinase & $44.68 / 8.31$ & Kinase transferase & $6.3^{* *}$ \\
\hline \multirow{4}{*}{ Transport proteins } & Serum albumin & $6.99 / 5.51$ & $\begin{array}{l}\text { Binding capacity for } \mathrm{Ca}^{2+}, \mathrm{Na}^{+}, \mathrm{K}^{+} \text {, fatty } \\
\text { acids, hormones, bilirubin and drugs }\end{array}$ & $3.4^{*}$ \\
\hline & Adipocyte fatty acid binding protein & $14.88 / 6.34$ & Lipid binding, transporter activity & $5.1^{*}$ \\
\hline & $\begin{array}{l}\text { RBP7 Similar to retinoid binding } \\
\text { protein } 7\end{array}$ & $29.03 / 8.66$ & Retinoid binding, transporter activity & $4.6^{*}$ \\
\hline & Transthyretin (TTR) $15 \mathrm{kD}$ protein & $14.96 / 4.98$ & Thyroid hormone-binding protein & $-4.2^{*}$ \\
\hline
\end{tabular}

Note: Positive $\mathrm{t}$-values indicate upregulation; negative values indicate downregulation. ${ }^{\star} \mathrm{P} \leq 0.05,{ }^{* *} \mathrm{P} \leq 0.01 .{ }^{1}$ Three separate upregulated spots were identified to be apolipoprotein A-I.

\section{Discussion}

In the present study, 1-day-old SPF chickens were infected with the MDV-1 RB1B strain, and by combined 2-DE and MALDI-TOF MS analyses, 16 proteins with markedly altered expression patterns were identified in the skin of infected birds $28 \mathrm{dpi}$. These proteins could be classified into 5 functional groups: immune-related, cell regulatory, cytoskeletal, metabolism-related and transport proteins.

Among the proteins identified in this study, beta 2-microglobulin $(\beta 2 \mathrm{M})$, which was newly induced in the infected group, was of significant interest. Real-time quantitative PCR of $\beta 2 \mathrm{M}$ mRNA confirmed that the associated gene expression level in the infected group was much higher than that in the control group. $\beta 2 \mathrm{M}$ is one component of MHC class
I, which is found on the surface of all nucleated cells. In this study, the absence of detection of $\beta 2 \mathrm{M}$ on control maps may be due to insufficient sensitivity of staining. MHC class I molecules play important roles in presenting endogenous antigens such as viral proteins and tumor proteins to cytotoxic T-cells (CTLs). Many infectious agents, including herpesviruses, have developed mechanisms to evade CD8+ CTLs by interfering with MHC class I antigen processing and presentation (Johnson and Hill, 1998; Petersen et al., 2003; van der Meulen et al., 2006).

MDV infection led to downregulation of MHC class I molecules in vitro and in tumor cells, but the relevance of this mechanism in the pathogenesis of MDV infection is still poorly understood (Gimeno et al., 2001; Hunt et al., 2001; Levy et al., 2003). We have found that $\beta 2 \mathrm{M}$ expression 
Table 3. CT values of beta-2 microglobulin and beta-actin genes amplified by real-time quantitative PCR

\begin{tabular}{|c|c|c|c|c|c|c|}
\hline Sample & $\begin{array}{c}\beta-2 \text { microglobulin } \mathrm{CT} \\
\text { mean } \pm \mathrm{SD}\end{array}$ & $\beta$-actin CT mean \pm SD & $\triangle \mathrm{CT}$ & $\triangle \mathrm{CT}$ mean & $\triangle \triangle \mathrm{CT}$ & $2^{-\triangle \Delta C T}$ \\
\hline $\mathrm{I}_{1}$ & $18.488 \pm 0.054$ & $16.676 \pm 0.202$ & 1.812 & 2.145 & -1.948 & 3.86 \\
\hline $\mathrm{I}_{2}$ & $19.251 \pm 0.112$ & $16.952 \pm 0.203$ & 2.229 & & & \\
\hline $\mathrm{I}_{3}^{2}$ & $19.458 \pm 0.031$ & $17.064 \pm 0.089$ & 2.394 & & & \\
\hline $\mathrm{C}_{1}$ & $20.722 \pm 0.042$ & $18.371 \pm 0.414$ & 2.351 & 4.093 & & \\
\hline $\mathrm{C}_{2}$ & $21.237 \pm 0.061$ & $17.183 \pm 0.132$ & 5.054 & & & \\
\hline $\mathrm{C}_{3}$ & $21.817 \pm 0.047$ & $16.943 \pm 0.235$ & 4.874 & & & \\
\hline
\end{tabular}

Note: sample names $\mathrm{I}_{1}, \mathrm{I}_{2}$ and $\mathrm{I}_{3}$ refer to three different individuals from the infected group, $\mathrm{C}_{1}, \mathrm{C}_{2}$ and $\mathrm{C}_{3}$ refer to three different individuals from the control group.

is decreased in the bursa of Fabricius in chickens infected with MDV (Lu et al., 2010). The decline of $\beta 2 \mathrm{M}$ may help the virus escape from host immune recognition and thus may contribute to host immunosuppression. However, the expression of MHC class I molecules in cells infected with MDV seems to be variable. Some studies have reported the increased expression of MHC class I molecules and the $\beta 2 \mathrm{M}$ gene in CEFs infected with MDV, MD lymphoma and the feather pulp of MDV-infected chickens (Abdul-Careem et al., 2008; Burgess and Davison, 2002; Morgan et al., 2001). These findings show that host responses are generated in the skin and feathers, which could be exploited as targets for developing strategies to control MDV infection in the FFE, thus limiting horizontal virus transmission. However, why these host-mediated responses are not effective in disruption of the productive phase of MDV infection remains unclear. Levy et al. (2003) have reported the downregulation of MHC class I expression in CEFs infected with the MDV strain RB1B; however, the downregulation of the MHC-I a chain is greater than that of $\beta 2 \mathrm{M}$. These results led to the proposal that MDV may encode an alternative molecule to replace the chicken a chain to aid the virus both in the evasion of CTL recognition and in survival during natural killer cell attack. These observations raise an important question: what is the role of $\beta 2 \mathrm{M}$ in MDV-infected chickens? Heikkila et al. reported that RNA interference-induced silencing of $\beta 2 \mathrm{M}$ efficiently inhibited coxsackievirus A9 (CAV9) infection of A549 human lung carcinoma cells and caused CAV9 to accumulate on the cell surface. These results suggested that $\beta 2 \mathrm{M}$ was involved in internalization of the virus (Heikkila et al., 2010). Therefore, we speculate that $\beta 2 \mathrm{M}$ may be involved in the process of viral adsorption and penetration and may promote viral replication and proliferation in FFE. However, the specific mechanisms underlying these processes require further investigation.

In addition to the increased expression of $\beta 2 \mathrm{M}$ following MDV infection, the levels of $\beta 2 \mathrm{M}$ are elevated in multiple human tumor types. Moreover, the increased tissue/serum level of $\beta 2 \mathrm{M}$ is associated with cancer cell migration and invasion (Canovas et al., 2010; Triozzi et al., 2013). Recent studies have demonstrated that tumor cells treated with antibodies specific for $32 \mathrm{M}$ or $\mathrm{MHC}$ class I molecules undergo apoptosis in vitro and in vivo (in a mouse model). These findings suggest that targeting of either $\beta 2 \mathrm{M}$ or MHC class I offers a potential therapeutic approach for the treatment of $\beta 2 \mathrm{M} / \mathrm{MHC}$ class I-expressing malignancies (Cao et al., 2011; Huang et al., 2010; Shi et al., 2009; Triozzi et al., 2013; Yang and Yi, 2010). However, the specific function of $\beta 2 \mathrm{M}$ in modulating tumorigenesis is poorly understood. MD provides a good model for the study of human tumorigenesis. Therefore, additional study of the role of $\beta 2 \mathrm{M}$ in MDV pathogenesis would provide important insight into the mechanisms controlling tumorigenesis in specific human tumors.

In the present study, three up-regulated protein spots were identified as apolipoprotein AI (apo AI). Using online software (www.expasy.org) to predict the sites of phosphorylation and glycosylation, we found that apo AI contained several potential phosphorylation sites and two potential O- $\beta$-GlcNAc glycosylation sites. Thus, it is possible that apo AI was modified after translation in MDV-infected chickens. Previous studies have shown that the amphipathic $\alpha$-helical domains of human apo AI have broad anti-infective and antiviral activity (Owens et al., 1990; Srinivas et al., 1991). The sequence of chicken apo $\mathrm{AI}$ is homologous to that of mammalian apo AI, possessing an amphipathic $\alpha$-helical domain. Moreover, the tissue distributions and functions of chicken apo AI are analogous to those of mammalian apo E (Rajavashisth et al., 1987), which also has broad antiviral activity (Bhattacharjee et al., 2009; Dobson et al., 2006). In addition, apo AI expression is found to be increased in the bursa of Fabricius (Lu et al., 2010) and feather pulp in chickens infected with MDV (Chen et al., 2011). Altogether, these results suggest that apo AI plays an important antiviral role during MDV infection.

It is well known that tumor cells derive much of their energy for survival and growth from glycolysis, whereas normal cells depend mainly on aerobic oxidation. Therefore, glycolytic genes are often overexpressed in tumor cells (Daskalow et al., 2009; Wolf et al., 2011; Zhou et al., 2011). High rates of glycolysis and the activation of the hexosamine biosynthetic pathway may favor cancer cell survival and 
aggressiveness (Guillaumond et al., 2013). In the current study, TPI1, PGK1 and beta-enolase enzymes, which are all components of the glycolytic pathway, were up-regulated in MDV-infected chickens. Tumor cells infiltrating the skin and feather pulp may contribute to the increased expression of these proteins in the infected group.

In conclusion, $\beta 2 \mathrm{M}$ and other proteins identified in this study were associated with a variety of cellular processes such as antigen processing and presentation, cytoskeletal changes and energy metabolism. Targeting $\beta 2 \mathrm{M}$ or MHC class I molecules may provide a potential therapeutic approach for treatment of $\beta 2 \mathrm{M} / \mathrm{MHC}$ class I-expressing malignancies.

Acknowledgements. This research was supported by the National Natural Science Foundation of China (31272560, 31072135), Major Basic Research of the Natural Science Foundation of the Jiangsu Higher Education Institutions of China (Grant No. 12KJA23001), The Program for Changjiang Scholars and Innovative Research Team in University (IRT0978) and A Project Funded by the Priority Academic Program Development of Jiangsu Higher Education Institutions.

\section{References}

Abdul-Careem MF, Hunter BD, Nagy E, Read LR, Sanei B, Spencer JL, Sharif S (2006): Development of a real-time PCR assay using SYBR Green chemistry for monitoring Marek's disease virus genome load in feather tips. J. Virol. Methods 133, 34-40. http://dx.doi.org/10.1016/j.jviromet.2005.10.018

Abdul-Careem MF, Hunter BD, Sarson AJ, Parvizi P, Haghighi HR, Read L, Heidari M, Sharif S (2008): Host responses are induced in feathers of chickens infected with Marek's disease virus. Virology 370, 323-332. http://dx.doi.org/10.1016/j.virol.2007.09.013

Abdul-Careem MF, Read LR, Parvizi P, Thanthrige-Don N, Sharif S (2009): Marek's disease virus-induced expression of cytokine genes in feathers of genetically defined chickens. Dev. Comp. Immunol. 33, 618-623. http://dx.doi.org/10.1016/j.dci.2008.11.003

Baigent SJ, Smith LP, Currie RJ, Nair VK (2005): Replication kinetics of Marek's disease vaccine virus in feathers and lymphoid tissues using PCR and virus isolation. J. Gen. Virol. 86, 2989-2998. http://dx.doi.org/10.1099/vir.0.81299-0

Bhattacharjee PS, Neumann DM, Hill JM (2009): A human apolipoprotein $\mathrm{E}$ mimetic peptide effectively inhibits HSV-1 TK-positive and TK-negative acute epithelial keratitis in rabbits. Curr. Eye Res. 34, 99-102. http://dx.doi.org/10.1080/02713680802647662

Burgess SC, Davison TF (2002): Identification of the neoplastically transformed cells in Marek's disease herpesvirus-induced lymphomas: recognition by the monoclonal antibody AV37. J. Virol. 76, 7276-7292. http://dx.doi.org/10.1128/JVI.76.14.7276-7292.2002
Calnek BW (2001): Pathogenesis of Marek's disease virus infection. Curr. Top. Microbiol. Immunol. 255, 25-55. http://dx.doi.org/10.1007/978-3-642-56863-3 2

Calnek BW, Adldinger HK, Kahn DE (1970): Feather follicle epithelium: a source of enveloped and infectious cell-free herpesvirus from Marek's disease. Avian Dis. 14, 219-233. http://dx.doi.org/10.2307/1588466

Canovas A, Alonso JJ, Barreiro G, Aguirre C (2010): Prognostic factors in follicular lymphoma: the importance of beta- 2 microglobulin. Tumori 96, 117-121.

Cao Y, Lan Y, Qian J, Zheng Y, Hong S, Li H, Wang M, Kwak LW, Lin D, Yang J, Yi, Q (2011): Targeting cell surface beta(2) -microglobulin by pentameric IgM antibodies. Br. J. Haematol. 154, 111-121. http://dx.doi.org/10.1111/j.1365-2141.2011.08714.x

Chen X, Lu Z, Qian K, Jin W, Wang Y, Qin A (2011): [Proteomics analysis of feather pulp from chickens infected with very virulent strain of Marek's disease virus]. Wei Sheng Wu Xue Bao 51, 1398-1406.

Daskalow K, Pfander D, Weichert W, Rohwer N, Thelen A, Neuhaus P, Jonas S, Wiedenmann B, Benckert C, Cramer T (2009): Distinct temporospatial expression patterns of glycolysis-related proteins in human hepatocellular carcinoma. Histochem. Cell Biol. 132, 21-31. http://dx.doi.org/10.1007/s00418-009-0590-4

Dobson CB, Sales SD, Hoggard P, Wozniak MA, Crutcher KA (2006): The receptor-binding region of human apolipoprotein $\mathrm{E}$ has direct anti-infective activity. J. Infect. Dis. 193, 442-450. http://dx.doi.org/10.1086/499280

Gimeno IM, Witter RL, Hunt HD, Lee LF, Reddy SM, Neumann U (2001): Marek's disease virus infection in the brain: virus replication, cellular infiltration, and major histocompatibility complex antigen expression. Vet. Pathol. 38, 491-503. http://dx.doi.org/10.1354/vp.38-5-491

Guillaumond F, Leca J, Olivares O, Lavaut MN, Vidal N, Berthezene P, Dusetti NJ, Loncle C, Calvo E, Turrini O, Iovanna JL, Tomasini R, Vasseur S (2013): Strengthened glycolysis under hypoxia supports tumor symbiosis and hexosamine biosynthesis in pancreatic adenocarcinoma. Proc. Natl. Acad. Sci. U S A 110, 39193924 http://dx.doi.org/10.1073/pnas.1219555110

Heikkila O, Susi P, Tevaluoto T, Harma H, Marjomaki V, Hyypia T, Kiljunen S (2010): Internalization of coxsackievirus A9 is mediated by $\{$ beta\}2-microglobulin, dynamin, and Arf6 but not by caveolin-1 or clathrin. J. Virol. 84, 3666-3681. http://dx.doi.org/10.1128/JVI.01340-09

Hu X, Qin A, Qian K, Shao H, Yu C, Xu W, Miao J (2012): Analysis of protein expression profiles in the thymus of chickens infected with Marek's disease virus. Virol. J. 9, 256-283. http://dx.doi.org/10.1186/1743-422X-9-256

Huang WC, Zhau HE, Chung LW (2010): Androgen receptor survival signaling is blocked by anti-beta2-microglobulin monoclonal antibody via a MAPK/lipogenic pathway in human prostate cancer cells. J. Biol. Chem. 285, 7947-7956. http://dx.doi.org/10.1074/jbc.M109.092759

Hunt HD, Lupiani B, Miller MM, Gimeno I, Lee LF, Parcells MS (2001): Marek's disease virus down-reg- 
ulates surface expression of MHC (B Complex) Class I (BF) glycoproteins during active but not latent infection of chicken cells. Virology 282, 198-205. http://dx.doi.org/10.1006/viro.2000.0797

Johnson DC, Hill AB (1998): Herpesvirus evasion of the immune system. Curr. Top. Microbiol. Immunol. 232, 149-177. http://dx.doi.org/10.1007/978-3-642-72045-1 8

Levy AM, Davidson I, Burgess SC, Dan Heller E (2003): Major histocompatibility complex class I is downregulated in Marek's disease virus infected chicken embryo fibroblasts and corrected by chicken interferon. Comp. Immunol. Microbiol. Infect. Dis. 26, 189-198. http://dx.doi.org/10.1016/S0147-9571(02)00055-3

Li YP, Bang DD, Handberg KJ, Jorgensen PH, Zhang, M. F. (2005): Evaluation of the suitability of six host genes as internal control in real-time RT-PCR assays in chicken embryo cell cultures infected with infectious bursal disease virus. Vet. Microbiol. 110, 155-165. http://dx.doi.org/10.1016/j.vetmic.2005.06.014

Livak KJ, Schmittgen TD (2001): Analysis of relative gene expression data using real-time quantitative PCR and the 2(-Delta Delta C(T)) Method. Methods 25, 402-408. http://dx.doi.org/10.1006/meth.2001.1262

Lu Z, Qin A, Qian K, Chen X, Jin W, Zhu Y, Eltahir YM (2010): Proteomic analysis of the host response in the bursa of Fabricius of chickens infected with Marek's disease virus. Virus Res. 153, 250-257. http://dx.doi.org/10.1016/j.virusres.2010.08.010

Morgan RW, Sofer L, Anderson AS, Bernberg EL, Cui J, Burnside J (2001): Induction of host gene expression following infection of chicken embryo fibroblasts with oncogenic Marek's disease virus. J. Virol. 75, 533-539. http://dx.doi.org/10.1128/JVI.75.1.533-539.2001

Owens BJ, Anantharamaiah GM, Kahlon JB, Srinivas RV, Compans RW, Segrest JP (1990): Apolipoprotein A-I and its amphipathic helix peptide analogues inhibit human immunodeficiency virus-induced syncytium formation. J. Clin. Invest. 86, 1142-1150. http://dx.doi.org/10.1172/JCI114819

Petersen JL, Morris CR, Solheim JC (2003): Virus evasion of MHC class I molecule presentation. J. Immunol. 171, 4473-4478.

Rajavashisth TB, Dawson PA, Williams DL, Shackleford JE, Lebherz H, Lusis AJ (1987): Structure, evolution, and regulation of chicken apolipoprotein A-I. J. Biol. Chem. 262, 7058-7065.
Shi C, Zhu Y, Su Y, Chung LW, Cheng T (2009): Beta2microglobulin: emerging as a promising cancer therapeutic target. Drug Discov. Today 14, 25-30. http://dx.doi.org/10.1016/j.drudis.2008.11.001

Srinivas RV, Venkatachalapathi YV, Rui Z, Owens RJ, Gupta KB, Srinivas SK, Anantharamaiah GM, Segrest JP, Compans RW (1991): Inhibition of virus-induced cell fusion by apolipoprotein A-I and its amphipathic peptide analogs. J. Cell Biochem. 45, 224-237. http://dx.doi.org/10.1002/jcb.240450214

Thanthrige-Don N, Abdul-Careem MF, Shack LA, Burgess SC, Sharif S (2009): Analyses of the spleen proteome of chickens infected with Marek's disease virus. Virology 390, 356-367. http://dx.doi.org/10.1016/j.virol.2009.05.020

Thanthrige-Don N, Parvizi P, Sarson AJ, Shack LA, Burgess SC, Sharif S (2010): Proteomic analysis of host responses to Marek's disease virus infection in spleens of genetically resistant and susceptible chickens. Dev. Comp. Immunol. 34, 699-704. http://dx.doi.org/10.1016/j.dci.2010.01.016

Triozzi PL, Elson P, Aldrich W, Achberger S, Tubbs R, Biscotti CV, Singh AD (2013): Elevated blood beta-2 microglobulin is associated with tumor monosomy- 3 in patients with primary uveal melanoma. Melanoma Res. 23, 1-7. http://dx.doi.org/10.1097/CMR.0b013e32835b7154

van der Meulen KM, Favoreel HW, Pensaert MB, Nauwynck HJ (2006): Immune escape of equine herpesvirus 1 and other herpesviruses of veterinary importance. Vet. Immunol. Immunopathol. 111, 31-40. http://dx.doi.org/10.1016/j.vetimm.2006.01.006

Wolf A, Agnihotri S, Micallef J, Mukherjee J, Sabha N, Cairns R, Hawkins C, Guha A (2011): Hexokinase 2 is a key mediator of aerobic glycolysis and promotes tumor growth in human glioblastoma multiforme. J. Exp. Med. 208, 313-326. http://dx.doi.org/10.1084/jem.20101470

Yang J, Yi Q (2010): Killing tumor cells through their surface beta(2)-microglobulin or major histocompatibility complex class I molecules. Cancer 116, 1638-1645. http://dx.doi.org/10.1002/cncr.24953

Zhou Y, Shingu T, Feng L, Chen Z, Ogasawara M, Keating MJ, Kondo S, Huang P (2011): Metabolic alterations in highly tumorigenic glioblastoma cells: preference for hypoxia and high dependency on glycolysis. J. Biol. Chem. 286, 32843-3253. http://dx.doi.org/10.1074/jbc.M111.260935 